\title{
Relationship between the Initial Activity and Thermal Inactivation of Ca-ATPase from Milkfish Actomyosin and Myosin
}

\author{
Wen-Ching Ko and Shwu-Yun Shieh
}

Department of Food Science, National Chung Hsing University, Kuokang Road 250, Taichung, Taiwan, ROC

(Received July 25, 1994)

Key words: thermal inactivation, Ca-ATPase, initial activity, actomyosin, myosin, milkfish

It is well known that storage or processing of fish causes actomyosin or myosin denaturation and Ca-ATPase inactivation. $^{1-4)}$ But limited work has been done on the contribution to the decrease in the initial activity, the activity before thermal treatment, and to the susceptibility for thermal inactivation. Actomyosin and myosin with different Ca-ATPase specific activities were prepared from milkfish by storing the proteins in ice for various periods and the relationship of initial activity of Ca-ATPase and its ther-

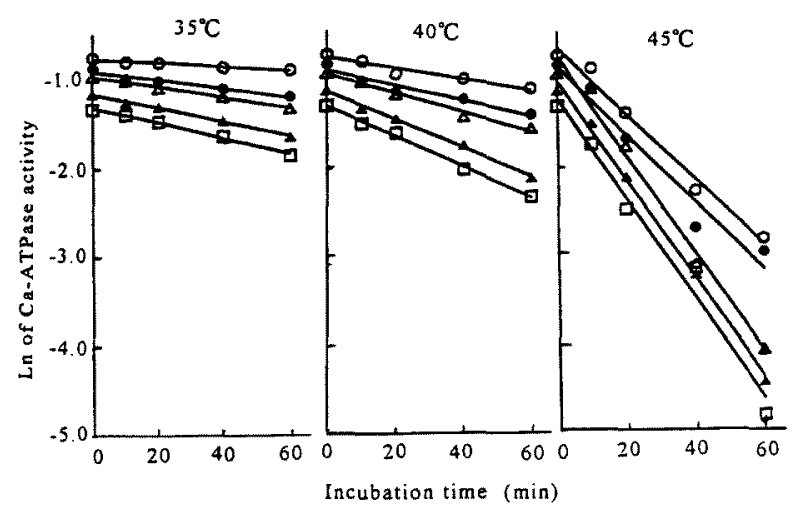

Fig. 1. Relationship between initial Ca-ATPase activity and its thermal inactivation of milkfish actomyosin. The actomyosin $(3 \mathrm{mg} / \mathrm{ml}, 0.6$ $\mathrm{M} \mathrm{KCl}, \mathrm{pH} 7.0$ ) with initial activity of $0.468(0), 0.419(\bullet), 0.381$ $(\triangle), 0.314(\triangle)$, and $0.264(\square) \mu \mathrm{mol} \mathrm{Pi} / \mathrm{min} \cdot \mathrm{mg}$ protein was heated at various temperatures.

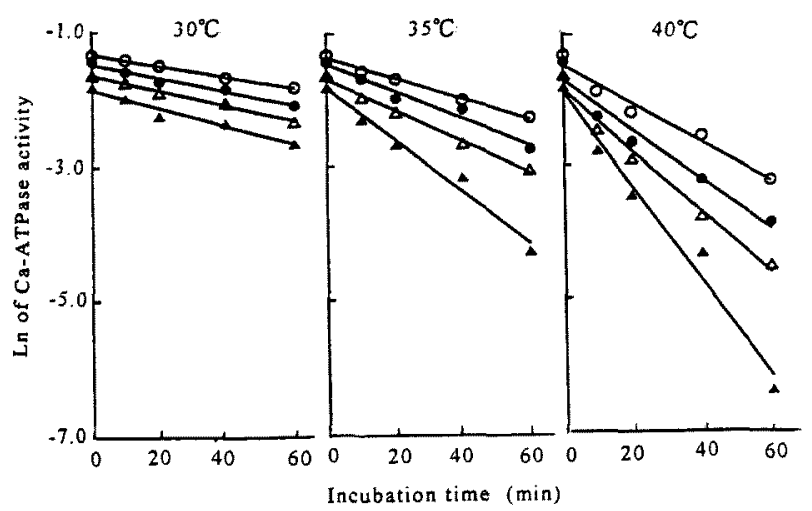

Fig. 2. Relationship between initial Ca-ATPase activity and its thermal inactivation of milkfish myosin. The myosin $(3 \mathrm{mg} / \mathrm{m} l, 0.6 \mathrm{M} \mathrm{KCl}$, $\mathrm{pH} 7.0)$ with initial activity of $0.266(0), 0.239(\bullet), 0.195(\triangle)$, and 0.165 (А) $\mu \mathrm{mol} \mathrm{Pi} / \mathrm{min} \cdot \mathrm{mg}$ protein was heated at various temperatures. mal inactivation was investigated.

The Ca-ATPase activity of milkfish declined from 0.468 to $0.264 \mu \mathrm{mol} \mathrm{Pi} / \mathrm{min} \cdot \mathrm{mg}$ protein for actomyosin and 0.266 to $0.165 \mu \mathrm{mol} \mathrm{Pi} / \mathrm{min} \cdot \mathrm{mg}$ protein for myosin during 21 days of iced storage. Figures 1 and 2 show that the heating temperature affected the rate of Ca-ATPase decrease for both actomyosin and myosin. Linear plots obtained indicate that those inactivation rates of Ca-ATPase activity can be expressed as a first order rate constant, $K_{d}$, as in case of other fish species. ${ }^{5,6)}$ Resistance of Ca-ATPase to thermal inactivation was also found to be closely related with its initial activity from those figures.

Tables 1 and 2 show $K_{d}$ increased with the increase of heating temperature at the same initial activity for actomyosin and myosin. On the other hand, $K_{d}$ also increased with the declination of initial activity. This indicated that Ca-ATPase with low initial activity expressed weak thermostability.

Thermostability of milkfish actomyosin and myosin was affected by initial activity. In spite of iced storage, activity declination was also observed in short duration. It is necessary to carry out experiments as rapidly as possible after preparation of actomyosin and myosin to prevent from aberration.

Table 1. The inactivation rate constant of milkfish actomyosin CaATPase at various initial activities

\begin{tabular}{cccccc}
\hline \multirow{2}{*}{$\begin{array}{c}\text { Heating } \\
\text { temperature } \\
\left({ }^{\circ} \mathrm{C}\right)\end{array}$} & \multicolumn{5}{c}{$\mathrm{K}_{\mathrm{d}}\left(10^{-s} \cdot \mathrm{sec}^{-1}\right)$} \\
\cline { 2 - 6 } & 0.468 & 0.419 & 0.381 & 0.314 & 0.264 \\
\hline 35 & 6.14 & 10.63 & 12.37 & 15.59 & 17.05 \\
40 & 12.51 & 16.45 & 20.28 & 29.00 & 31.11 \\
45 & 63.95 & 66.08 & 95.01 & 95.29 & 96.31 \\
\hline
\end{tabular}

Table 2. The inactivation rate constant of milkfish myosin Ca-ATPase at various initial activities

\begin{tabular}{ccccc}
\hline $\begin{array}{c}\text { Heating } \\
\text { temperature } \\
\left({ }^{\circ} \mathrm{C}\right)\end{array}$ & \multicolumn{4}{c}{$\mathrm{K}_{\mathrm{d}}\left(10^{-5} \cdot \mathrm{sec}^{-1}\right)$} \\
\cline { 2 - 5 } & \multicolumn{3}{c}{ Initial activity $(\mu \mathrm{mole} \mathrm{Pi} / \mathrm{min} \cdot \mathrm{mg}$ protein $)$} \\
\cline { 2 - 5 } & 0.266 & 0.239 & 0.195 & 0.165 \\
\hline 30 & 17.79 & 20.78 & 22.62 & 26.09 \\
35 & 29.24 & 37.48 & 42.30 & 68.19 \\
40 & 52.14 & 65.96 & 80.31 & 121.97 \\
\hline
\end{tabular}




\section{References}

1) K. Arai and R. Takashi: Nippon Suisan Gakkaishi, 39, 533-541 (1973).

2) K. Arai and M. Fukuda: Nippon Suisan Gakkaishi, 39, 625-631 (1973).

3) T. Ito, N. Kitada, N. Yamada, N. Seki, and K. Arai: Nippon Suisan
Gakkaishi, 56, 1647-1653 (1990).

4) T. Tambo, N. Yamada, and N. Kitada: Nippon Suisan Gakkaishi, 58, 677-683 (1992).

5) A. Hashimoto, A. Kobayashi, and K. Arai: Nippon Suisan Gakkaishi, 48, 671-684 (1982).

6) A. Hashimoto and K. Arai: Nippon Suisan Gakkaishi, 44, 1389 1393 (1978). 